\title{
Implementing Inclusive Education: What are Elementary Teacher Obstacles? Case Study in East Jakarta, Indonesia
}

\author{
Yubaedi Siron \\ Syarif Hidayatullah State Islamic University (UIN) \\ Jakarta, Indonesia \\ email: sironyubaedi91@gmail.com
}

\author{
Rachmat Mulyono \\ Syarif Hidayatullah State Islamic University (UIN) \\ Jakarta, Indonesia \\ email: rachmat.mulyono@uinjkt.ac.id
}

\begin{abstract}
Implementation of Inclusive Education (IE) has many obstacles for teachers in its implementation in East Jakarta. The objective of this research is to describe the difficulties experienced by elementary school teachers in regular schools to implement IE. This study involved 31 elementary school teachers in East Jakarta. Purpossive sampling method was used, while data analyze used Miles and Huberman technique to data reduction, data display, and verification. This study revealed the experience of teacher obstacles in teaching skills in inclusive classrooms which include: how to make inclusive lesson plan and individualized education program (IEP), implementation in inclusive learning activities, inclusive classroom management, suitable inclusive learning methods, use of instructional media, and evaluation in IE. In addition, teachers have several difficulties to manage, such as low parental involvement, children with special need's peers, and school facilities.
\end{abstract}

Keyword: IE; Teachers Obstacle; Elementary Student.

\section{INTRODUCTION}

Inclusive Education (IE) has been described as provision for all students including those with disabilities, gifted, and all multiculture in regular school. It give equitable opportunities to receive effective educational services. IE provide not only for special need children, but also provide education without discrimination, accept all diversity, religion, gender, social economics, culture, and etnic[1] [2] [3].

The objective of the study is to describe the difficulties experienced by teachers in practicing IE in their schools. In Indonesia, IE becomes a challenge for teachers to practice it, especially in Primary School (PS). The practice of IE is a new thing which not all province have implemented it yet. The number of children aged 10 to $14-$ year-old in Indonesia who experienced disability, 70,865 children had visual impairment, 860 children had heard impairment, 176,020 children had physical disability, 92,949 children had learning difficulties, 87,640 children had behavioral and emotional disorders, and 89,907 children had communication disorders. There are still many children with special needs who had lack of quality and education approriately. Only a small number has been accommodated in a special education (SE) or a similar type of segregation school [4] [5].

IE was attended by 15,144 students held in 811 schools, covering 21 kindergartens, 252 elementary schools, 80 junior high schools, and 58 high schools [6]
However, former research was investigated the lack of inclusion participants from persons with disabilities in intelligence, particularly mental retardation. Generally, public schools refuse to accept SNC for various reasons, such as 1) school facilities that it could not support inclusion programs; 2) the teacher's capability to treat the SNC, even they have been trained; 3) the procurement of special teachers who provide assistance to the SNC has not been in accordance with the needs in every school; 4) inclusion classes require various curriculum modifications, learning process and evaluation of learning outcomes. Furthermore, many parents reject the SNC to join with their children in regular class [7].

Education for children with special needs has been included in the Act No 20, 2003 about National Education System. It is stipulated in article 15 that special education is an education for students with disabilities or learners who have extraordinary intelligence held inclusively or in the form of special educational units at the level of primary and secondary education [8].

In Jakarta, policy for new student selection in primary school used online system. The requirement of selection only sorted by the age of the children. In several cases, the selection committee did not know the ability of prospective children. Thus, many public schools which are not ready to practice inclusive schools, have some students with special needs. In fact, the school had not been able physically and nonphysically to implement an inclusive school, both from teacher capabilities, infrastructure, and other supporting facilities.

The policy becomes a new problem when teachers are not ready to guide the SNC and they have no skills in dealing with children with special needs. The policy has not been accompanied by the preparation of qualified resources and training for teachers to provide inclusive schools.

Though teachers are one of the determinants of the success of IE, because teachers have a vital role in managing all learning process, planning, and the learning evaluation to measure the success of SNC in following each material of learning [9].

The success of IE is exemplified by research conducted by Freeman and Alkin in implementation of IE in the United States, stating that individuals with mental retardation which mild category (educable children) achieve positive outcomes when educated at inclusive classes rather than special classes in exceptional schools, 
especially the progress in their social skills and special competencies [6] [20].

\section{METHOD}

This research uses qualitative method. Data is taken by using semi structured interview. This research was conducted from January to March 2017. The focus of the research is the difficulties of primary school teachers in regular schools in implementing IE in East Jakarta. Jakarta is the one of region in Indonesia which have juridical act to implement inclusive education (Gubernatorial Decree No $116, / 2007$ ) [10], but it have several obstacles to implement it. This research involved 31 teachers in 31 different schools. The data conducted by purpossive sampling. The teachers who involved the study should have bachelor diploma and they should experienced in teaching in 3-15 years. Data analyzed by using Miles and Huberman model which includes data reduction, data presentation, and conclusion/verification (Miles and Huberman, 1992) [11].

\section{RESULT AND DISCUSSION}

\section{A. Lack of Knowledge}

Teachers do not have a good understanding about the SNC (W1, W7, W10, W11, W16), while the lack of socialization on IE by the government, thus creating schools in Jakarta still expect good socialization from the government to implement the good IE (W1, W7, W23). The quality of teachers in schools is not sufficient. [12]. This is because teachers are mostly not graduated from department of special need education when they pursued education in university (W4, W11). So, the teacher does not know how to teach the SNC appropriately. Teachers only teach SNCs based on how to teach other children regularly. In addition, teachers also cannot focus on teaching to the children with special needs. Teachers have difficulty in formulating curriculum, making Individual Education Plan (IEP), determining learning objectives, materials, and learning methods. These conditions also occured in Urban US schools [13]. Limitations of school facilities and the implementation of learning were not used the suitable media, and the learning environment which can foster SNC appropriately (W9).

\section{B. Too Much Burden in Class Activities \\ 1. Complicated Lesson Plan}

Curriculum content and material in Jakarta's schools are overlapping. Teachers have some works, and their works will be in trouble if they only concern to the special needs children. (W3).

As an inclusive teacher, they should prepare several different subject matters and consider the condition of the class, pupil activities in the class, and inclusion school. Teacher should know how many kinds of SNC in their class and how to treat them. Several teachers confused how to make IEP when they have some of SNC in their class and they should know the characteristics of their special need students deeply. (W24, W29)

Teachers have difficulties in preparing lessonplan for the learning process. Teachers are required to develop programs, syllabus and lesson plans which are appropriate to the condition of the special need children in their classroom. (W29, W25)

\section{Complicated Learning Processes}

Lack of teacher knowledge on IE, they prefer to implement general practice in their learning to the SNC. They have no special treatment to the SNC and they treat equally with the normal children (W31) (W11) (W25). For instance, student have different ability to understand about learning material. So, teacher should know how to explain to them in the different way and style, and treat them individually based on their needs (W29).

In short, many teachers got several obstacles and imbalances to practice an inclussive learning processes to the SNC. Generally, a regular learning distract by the SNC when the teacher have no capabilities to handle them (W29).

\section{Difficult to Manage Classroom}

In the management of inclusive classrooms, there are many obstacles to manage (W27, W30). For instance: a) The position of the SNC must be placed properly according to his disability (W29); b) In the classroom, the teacher must provide classical and individual service (W29); c) Teacher's treatment should be more serious to handle SNC in the inclusive class. (W29); d) In several cases, condition of classroom is difficult to handle because the SNC tend to disturb the others. The SNC become the center of attention in the classroom. It makes the distractions and need a hard effort to learn condusively. (W29) (W5) (W18).

In adddition, teachers have difficulties how to communicate effectively to the SNC (W27, W16). Beside that, special service to the SNC make the teacher need to use time efficiently (W5). Futhermore, Several SNCs could not follow the rule of learning processes in the classroom (W11).

\section{Inapropriate Learning Method}

Teacher have several obstacles to develop learning methods and suitable learning strategies for inclusive classroom with different characteristics of the children (W25). For the implementation of learning within the inclusive classroom, the teacher should choose and use appropriate teaching methods seriously. It approprite to the both of normal children and SNC (W29).

The common problem is many teachers prefer to choose learning of methods, strategies or teaching materials without any differentiation between normal student and SNC. Even, they tend to ignore the existence of SNC development. (W31).

\section{Inapropriate Learning Media}

Teachers have several obstacle to choose and use learning media for SNC. Teachers need to improve their knowledge how to provide suitable media to SNC. (W27, W31, W4).

\section{Incapable to Evaluate Learning}

Teachers have several problems in preparing evaluation for SNC. It is because teacher need to evaluate based on their special needs (W29). Inclusive class activities are not well organized. There is lack of good cooperation among teachers (W25). Altough, the teacher skills to evaluate the students in IE are important [14], the teacher have lack of cabalities to assess the students. 
Parent have lack of participation in inclusive learning. Parent attention to the SNC need to be improved. They prefer to spend their time only to earn money for living. In Jakarta, most of parent spent their time in the work place, and gather with their family in the night while They only have family time on the weekend. Several parents did not attend school to involve to their children education. He fully entrust their children to the school/teacher, whereas the teacher need parent collaboration to pursue the objective of the children education in the school and their home. (W4, W16, W11, W30).

A parent's understanding of SNC is very poor (W11, W16). There is a parent who give up to educate their children because of the children over behaviour. The parents prefer to ask help teacher to educate the children (W5). On the other hand, teacher need support and collaboration to treat SNC.(W5, W25). Moreover, There are many parent could not realize that their children become the part of the children with special needs. They argue that $\mathrm{SNC}$ is taboo. It is a negative stigma from society and school environment (W10, W11).

In addition, the lack of tolerance of the parents' normal children toward the SNC (W11). Parents who have normal children are worried about the influence of SNC on the attitude and behavior to their children. It is because as an elementary school children, especially in early grade, they prefer to imitate with the unique things that they saw (W16). The stigma of most people that special needs children could not do anything, so people sometime abuse the SNC.W25).

\section{Low Peer Support}

Student acceptance to the special need children are very low [15]. Generally, several students did not understand that special need children have special treatment, so they discriminate them both in socialization and play activities (W11, W27, W18). In other cases, United States have good model how to involved peer in IE settings and practices [16].

\section{E. Lack of Facilities and Supports}

School facilities are not support yet (W1, W4, W16). Government also did not prepare teacher to face the SNC children. Several teachers need to train periodically (W2, W11, W25). School need a shadow teacher (special need's teacher) to treat the SNC and give several helps and socializations to regular teacher (W11, W28). Beside that, parent perspective need to be open minded. Children ability affected by open minded of the parent who always fostering the SNC. (W6, W11). Then, teacher autonomy to implement the inclusive learning creatively and innovatively need to be support and facilitate by the professionals, government and stakeholders. (W9, W11). In Austria practices, the policy, appropriate curriculum and facilities could affect the good implementation in IE [17].

In addition, there are some teachers who find it difficult to get a place to give additional lessons. It is because all the rooms are used. The school is not provide additional classroom or special place to treat SNC (W18).

The principle of inclusion encourages all elements in learning to create an effective learning environment so that no learners are excluded or rejected due to their special needs/handicapped/impairment [18]. Through IE all students with different cultural backgrounds, physical, mental, social and cognitive conditions are entitled to a proper education. Learning environment is required to respond every advantages and disadvantages of the learners, so they can develop their talents and potentiality.

Analyzes the components of the implementation of IE consist of: 1) The process of identification and screening; 2) Individual Educational Program (IEP); 3) The physical environment of SNC to learn; 4) Methods and procedures of teaching in inclusive classroom [19].

\section{CONCLUSIONS}

This research can be concluded that there are still many obstacles faced by elementary school teachers in regular schools in implementing inclusive environment. Firstly, how to make IEP for SNC. Then, How to manage inclusive classroom and evaluate the learning processes. In addition, teachers are difficult to involve parent participation. Then how to involve peers to respect, give a chance, acceptance, and facilitate the SNC. Moreover, the facilitation from the government has not maximized yet. It is only limited to regulations that are not followed by real practices which implement the role models of good inclusive schools.

Follow up to the next researchers need to explore how far the Indonesian government intend to develop inclusive school in PS. The government should to provide more training for teacher who teach in inclusive classroom setting in reguler school. Beside that, the goverment should provide better facilities which appropiate to the students with special need. Then, it should evaluate the national government program. After that, It can develop the model of inclusive shool which appropriate with the Indonesian context and cases.

\section{REFERENCES}

[1] Michael Farrell. Debating Special Education. London and New York: Routledge, 2010.

[2] J. David Smith. Inclusion: Friendly School For All. [Inklusi: Sekolah Ramah untuk Semua terjemahan Denis, Ny Enrica]. Bandung: Penerbit Nuansa, 2006.

[3] George s. Morrison. 2008. Fundamentals of Early Childhood Education. 5th Edition. New Jersey: Pearson Education, Inc.

[4] Central Statistics Agency. Badan Pusat Statistik [BPS]. 2015. Hasil Survei Penduduk Antar Sensus (SUPAS) 2015. Accesed at http://bps.go.id/website/pdf_publikasi/ Penduduk-Indonesia-hasilSUPAS-2015_rev.pdf

[5] Otong Suhyanto, et all. The Effect of Motivation, Intention, and Teacher Comprehension to the Implementing Inclusive School.[Pengaruh Motivasi, Intensi, dan Pemahaman Guru terhadap Implementasi Sekolah Inklusif ] (Laporan Penelitian PIP dan Sains). Jakarta: UIN Syarif Hidayatullah. 2016.

[6] Directorat of Management for Special Education. Handbook of Inclusive Education.. Jakarta: Kemendikbud, Dirjen Dikdas, Direktorat PPKLK Dikdas. 2007.

[7] Martini Jamaris. Learning Difficulties, Perspective, Assessment, and Treatment. [Kesulitan Belajar, Perpektif, Asesmen, dan Penanggulangannya.] Jakarta: Ghalia Indonesia, 2014.

[8] Act No 20/2003 about National Education System of Republic of Indonesia.

[9] Mohammad Takdir Ilahi. Inclusive Education: Concept and Application [Pendidikan Inklusif. Konsep dan Aplikasi]. Yogyakarta: Ar Ruzz Media. 2013. 
[10] Gubernatorial Decree of Jakarta, Indonesia No 116/2007 about Implementation of Inclusive Education.

[11] Matthew B. Miles and Michael Huberman. Qualitative Data Analysis. London: Sage Publications, Inc. 1992.

[12] Itfaq Khaliq Khan, Suhjahat Haider Hashmi, Khanum. IE in Government Primary Schools: Teacher Perceptions. Journal of Education and Educational Development. Vol. 4 No. 1 June 2017.

[13] Shelley Zion and Donna M. Sobel. Mapping the Gaps: Redesigning a Teacher Education Program to Prepare Teachers for Inclusive, Urban U.S. Schools. Journal of the International Association of Special Education. Fall2014, Vol. 15 Issue 2, p63-73. 11p.

[14] Murat Gokdere. A Comparative Study of the Attitude, Concern, and Interaction Levels of Elementary School Teachers and Teacher Candidates towards Inclusive Education. Educational Sciences: Theory \& Practice. Autumn 2012, Vol. 12 Issue 4, p2800-2806. 7p.

[15] H Avcioğlu. (2017). Classroom teachers' behaviors and peers' acceptance of students in inclusive classrooms. Educational Sciences: $\begin{array}{llll}\text { Theory \& } \quad \text { Practice, } & \text { 463-492. }\end{array}$ http://dx.doi.org/10.12738/estp.2017.2.0034

[16] Megan Mackey. Inclusive Education in the United States: Middle School General Education Teachers' Approaches to Inclusion. International Journal of Instruction. Vol. 7 Issue 2, p5-20. 16p. Jul 2014.

[17] Susanne Schwab, et. all. Teaching Practices and Beliefs about Inclusion of General and Special Needs Teachers in Austria. Learning Disabilities. A Contemporary Journal. Vol. 13 Issue 2, p237-254. 18p. Dec 2015.

[18] Budiyanto, et all. Handbook of Training for Inclusive Education. [Modul Pelatihan Pendidikan Inklusif]. Jakarta: Kemendikbud, Dirjen Dikdas, Direktorat PPKLK Dikdas. 2012.

[19] Mitiku, Wondwosen. Yitayal Alemu, Semahegn Mengsit. Challenges and Opportunities to Implement IE. Asian Journal of Humanity, Art and Literature, Volume 1, No 2. 2014.

[20] S. F. N. Freeman \& M. C. Alkin. Academic and Social Attainments of Children with Mental Retardation in General and Special Education Settings. Remedial and Special Education, 21, 2-18. 2000 